\title{
THE FEMINIST CHALLENGE
}

THE MOVEMENT FOR WOMEN'S LIBERATION IN BRITAIN AND THE USA 
Also by David Bouchier

Idealism and Revolution 


\title{
THE \\ FEMINIST CHALLENGE
}

\author{
The Movement for Women's \\ Liberation in Britain and \\ the USA
}

DAVID BOUCHIER

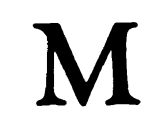

MACMILLAN PRESS

LONDON 
(C) David Bouchier 1983

All rights reserved. No part of this publication may be reproduced or transmitted, in any form or by any means, without permission

\author{
First published 1983 by \\ THE MACMILLAN PRESS LTD \\ London and Basingstoke \\ Companies and representatives \\ throughout the world
}

ISBN 978-0-333-32719-7

ISBN 978-1-349-17280-1 (eBook)

DOI 10.1007/978-1-349-17280-1

Typeset by Wessex Typesetters Ltd, Frome, Somerset 
For D. L. B. 


\section{Contents}

Acknowledgements $\quad$ ix

List of Abbreviations $\quad \mathbf{x}$

Introduction 1

1. False Promises: the Liberation and Domestication of Women $\quad 8$

The first wave of feminism $\quad 9$

After the vote $\quad 16$

$\begin{array}{ll}\text { Depression and war } & 19\end{array}$

Post-war affluence: women as consumers and producers 21

The liberalisation of sexuality $\quad 25$

The dream of domesticity: woman as housewife and

Women's life-chances in a changing world 32

Literary and intellectual debates $\quad 35$

Women and public policy $\quad 37$

Conditions for a new feminist movement 40

2. New Beginnings: the Rebirth of Feminism, 1963-9 42

Betty Friedan and the revival of liberal feminism 42

The National Organisation for Women (NOW) 44

The radical politics of the 1960s 48

The beginnings of women's liberation in the USA 52

The beginnings of women's liberation in Britain 55

Conclusion $\quad 60$

3. Mixed Messages: Theories of Modern Feminism 62

Basic principles $\quad 62$

Liberal feminism $\quad 64$

Socialist feminism $\quad 66$

Radical feminism $\quad 74$

Theory and practice $\quad 81$

Summary and conclusions $\quad 89$ 
4. High Hopes: the Growth of Feminism, 1970-5 93

Organising in Britain $\quad 93$

Organising in America $\quad 96$

Spreading the word $\quad 98$

Campaigning 105

Turning-point: the movement in 1975

5. New Directions: Policy Conflicts and Fresh

Campaigns, 1976-8

Unity and conflict in social movements $\quad 129$

Heterosexual feminism and political lesbianism $\quad 130$

Power and policy conflicts in the USA $\quad 136$

Old issues, new campaigns 140

$\begin{array}{ll}\text { Conclusions } & 146\end{array}$

6. Hostile Responses: the Enemies of Women's

$\begin{array}{ll}\text { Liberation } & 149\end{array}$

Opposition from men $\quad 151$

Opposition from women $\quad 157$

The organised opposition $\quad 160$

Hostility to feminism in the mass media and
commercial culture

$\begin{array}{ll}\text { Intellectuals and renegades } & 169\end{array}$

$\begin{array}{ll}\text { Conclusion } & 175\end{array}$

7. Testing Times: the Women's Movement Today 177

Balance-sheet: the state of the campaigns in Britain 183

Beyond the seven demands 191

More issues for the 1980s: women in politics 194

More issues for the 1980s: women, motherhood and the family

Balance-sheet: the American campaigns today 201

8. Unfinished Business: the Future of Feminism 208

$\begin{array}{ll}\text { The search for unity } & 209\end{array}$

$\begin{array}{ll}\text { Organising for change } & 217\end{array}$

Feminist futures $\quad 223$

Concluding note $\quad 232$

Further Reading $\quad 234$

References $\quad 239$

$\begin{array}{ll}\text { Index } & 246\end{array}$ 


\section{Acknowledgements}

This book reflects the work of many women. The knowledge on which it is based comes from the writers, historians, journalists, theoreticians, academics and political activists who created and recorded the women's movement. Many are named in the text, but many more must be anonymous; my debt to all of them is acknowledged unreservedly.

Equally indispensable were those individual women who gave their time for interviews and discussions, and to read and comment on various drafts of the emerging book. Participants in the Women and Men seminar at the State University of New York and many academic colleagues, feminists and friends among them, Liz Bargh, Kay Gough, Joyce Gelb and Susan Squier - provided insights, nuggets of information and constructive criticism.

Research in the USA was facilitated by a period of leave from the University of Essex, and the libraries of the Women's Research and Resources Centre, the Fawcett Society and the State University of New York provided much of the material some of it rare and difficult to obtain - on which the narrative is based.

It is no small irony that male authors so often acknowledge a friend and critic who made the whole thing possible, and that that person is almost invariably a woman. I can offer no variation on this traditional and slightly shameful theme. Diane Barthel read the manuscript line by line, challenged the arguments point by point, raised my consciousness on the frequent occasions when this was needed and provided the essential daily reassurances which every writer wants but not all are lucky enough to get. 


\section{List of Abbreviations}

ACAS Advisory, Conciliation and Arbitration Service

ACLU American Civil Liberties Union

ALRA Abortion Law Reform Association

APEX Association of Professional, Executive, Clerical and Computer Staff

ASTMS Association of Scientific, Technical and Managerial Staff

AUEW Amalgamated Union of Engineering Workers

CAG Cleaners' Action Group

CHE Campaign for Homosexual Equality

GND Campaign for Nuclear Disarmament

COHSE Confederation of Health Service Employees

EEC European Economic Community

EEOC Equal Employment Opportunities Commission (USA)

EOC Equal Opportunities Commission (Britain)

ERA Equal Rights Amendment

FEW Federally Employed Women

GLF Gay Liberation Front

GMWU General and Municipal Workers' Union

HRW Human Rights for Women

IMG International Marxist Group

IS International Socialists (Socialist Workers'

Party)

LARC Labour Abortion Rights Campaign

NAC National Abortion Campaign

NALGO National Association of Local Government Officers

NARAL National Abortion Rights Action League

NAWSA National American Women's Suffrage

Association

NCGL National Council for Civil Liberties

NOW National Organisation for Women 
NUPE National Union of Public Employees

NUSEC National Union of Societies for Equal Citizenship

NUT National Union of Teachers

NWPG National Women's Political Caucus

OWL Older Women's Liberation

PWC Professional Women's Caucus

SCUM Society for Cutting Up Men

SDS

Students for a Democratic Society

SNCC

Student Nonviolent Coordinating Committee

SPUC Society for the Protection of the Unborn Child

SWP Socialist Workers' Party

TGWU Transport and General Workers' Union

TUC Trades Union Congress

WAI Women Against Imperialism

WAR Women Against Rape

WARF Women Against Racism and Fascism

WAVAW Women Against Violence Against Women

WEAL Women's Equity Action League

WFH Wages for Housework

WIRES Women's Information, Referral and Enquiry

Service

WITCH Women's International Terrorist Conspiracy from Hell

WNCG Women's National Coordinating Committee

WONT Women Opposed to Nuclear Threat

WSPU Women's Social and Political Union

WWC Working Women's Charter

YSA Young Socialist Alliance 